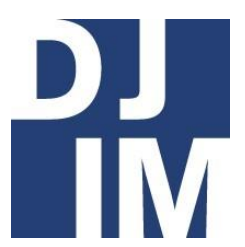

Volume 14

Spring

2018

djim.management.dal.ca |

\title{
Turning Exceptions into the Rule: Bridging the Gender Gap in Corporate Boardrooms and the C-Suites of Canadian Corporations
}

Justin Zuccon

School of Business, Dalhousie University

\begin{abstract}
This paper contextualizes the under-representation of women on the boards and in the executive suites of publicly-listed Canadian corporations by reviewing recent studies and statistics on the subject, dispelling traditional justifications for the gender imbalance and critically examining commonly proposed strategies to bridge the gap between policy and reality. The current "comply or explain" regime has proven to be ineffective. The author recommends that the provincial securities regulators band together to institute a mandatory quota system.
\end{abstract}

"Real change will come when powerful women are less of an exception" (Sandberg, 2013, p. 50).

\section{Introduction}

Following the release of a 2014 report prepared by the Advisory Council for Promoting Women on Boards, Parliament pledged to have women comprise at least $30 \%$ of the boards of publicly-traded Canadian corporations by 2019 (Increasing the Representation of Women on Canadian Boards, 2016). The deadline is soon approaching and while some progress has been made to increase female participation in all areas of the workforce in the last three decades, the 30\% target at the directorship and executive suite levels appears out of reach (Good for Business, 2014, p. 1).

As it stands in 2018, gender parity in corporate Canada remains more the 
exception than the norm. The statistics are startling: Canadian men are almost three times more likely to hold senior positions than their female counterparts (Women Still Missing, 2011). The boardrooms of more than half the reporting issuers on the Toronto Stock Exchange are entirely maledominated (CSA Multilateral Staff Notice, 2015, p. 11). Although the recent federal budget acknowledges the glaring gender gap that exists at the highest levels of corporate leadership, no comprehensive proposals have been tabled to bridge this impasse.

This paper analyzes the imbalance within the uppermost echelons of Canadian corporations as well as some common explanations for the underrepresentation of women in senior positions as directors and executives; the "comply or explain" amendment to National Instrument 58-101 ("NI 58-101") and its efficacy (or lack thereof); and, the benefits of adopting a more radical approach to tackling the gender gap through the implementation of mandatory quotas.

\section{The current landscape}

As of May 2017, 37\% of management positions at Canadian companies were held by women (Catalyst Inc., 2017) and yet women account for fewer than $12 \%$ of corporate directorship seats (Lu, 2016). Although the percentage of women in Canadian boardrooms has doubled since the early 1990s (Burke, 2000), current trends suggest that improvements to the gender ratio have reached a boiling point.
The advances achieved in the last ten years may in fact be reversing. A total of four TSX-listed companies have achieved equal representation on its boards: Dream Unlimited, HSBC Bank Canada, Sienna Senior Living and TVA group Inc. (MacDougall, 2016, p.36). This is one fewer than in 2016. The 521 board vacancies that arose in 2016, only 76 were filled by women (Lu, 2016). Without improvement in the vacancy filling rates, some critics argue the 30 percent target may not be achieved for several decades (Financial Post, 2016). Given Canada's progressive stance towards the rights of women, these low directorship percentages and appointment numbers are disappointing from a corporate-social responsibility perspective.

Studies have shown that increased gender diversity on corporate boards and at the executive level directly translate to improved financial performance and higher employee retention. In other words, equal representation contributes to the triple bottom line and raises a company's social, environmental, and financial potential. Credit Suisse recently conducted a study of over 3000 companies in various sectors. The study quantified the benefits of equal representation (Credit Suisse, 2014). The report concluded that gender diversity "coincide[s] with better corporate financial performance and higher stock market valuations" (Credit Suisse, 2014, p. 4). In fact, companies with more than one woman on their board have returned on average a compound $3.7 \%$ on equity annually since 2005 (Credit Suisse, 2014, p.

Turning Exceptions into the Rule 
5). This trend of outperformance persists across the globe and amongst various industries (see Appendix 1). Other industry stakeholders have conducted similar studies and have reached the same conclusion: gender parity makes companies more productive.

For academics and business people alike, the debate surrounding equal representation is no longer focused on whether it is needed. The debate is now how it should be implemented and how soon it can be accomplished. Catalyst Inc. (Catalyst), an international organization founded in 1962, which advocates for greater workplace inclusivity, has been actively campaigning to increase the awareness of the benefits of greater gender diversity in corporate boardrooms. Catalyst made a call to action encouraging Canadian corporations to exceed the 30\% target by 2017- two years earlier than the official Government of Canada deadline (Catalyst Inc., 2015). Signatories to the Catalyst Accord include Air Canada, Bell Canada, CIBC, National Bank, Ontario Power Generation, Scotiabank and RBC. The Accord has also been endorsed by the Ontario Government, which plans to staff $40 \%$ of public boards with female appointees by 2019 (Catalyst Inc., 2016).

While grassroots efforts from groups such as Catalyst have compelled larger organizations to re-evaluate their corporate governance policies, the gender gap persists. Ageism and the multi-jurisdictional nature of Canadian securities legislation are two typical reasons that academics have suggested contribute towards the continued predominance of corporate Canada's "old boys' club" mentality. Both, however, do not provide comprehensive explanations for the disproportionately low number of female directors and executives in 2017.

\section{Age only partially explains the} imbalance

Age is one of the most important qualifications considered by nomination committees when making board appointments or when considering whether to hire potential executives. The progression from middle- to uppermanagement and eventually to the C-suites and boardrooms often takes decades. Corporations also give considerable weight to a candidate's experience and tenure when making their appointment and hiring decisions. It is not surprising, therefore, that the average age of directors of Canadian corporations is 61 (McFarland, 2015). In the late 1970s, virtually all persons in managerial positions were male. Both demographic trends and ageism could certainly explain why boardrooms at the turn of the century were composed of a disproportionate number of males. Those who started their careers in the 1970s would logically reach the pinnacles of their professional lives by the year 2000 and would be the most qualified candidates for executive-level promotions and directorship appointments at their respective companies. 
Average director age, however, is a metric that only partially explains the gender imbalances experienced today. The ascendancy of women in graduate business programs and upper management positions did not begin in earnest until the mid-1980s (Leighton, 2000, p. 255). This would explain why qualified and experienced middle-aged women who began their careers in the late 1980s and early 1990s have been slowly trickling into boardrooms and C-suites over the last thirty years, but does not adequately explain why they have not be doing so in greater numbers. Clearly, ageism is not the only force at play holding women back from becoming directors and senior executives and cannot, in itself, explain the current gender gap.

\section{Multi-jurisdictional nature of securities legislation}

Constitutionally speaking, the power to regulate the securities industry lies with the provinces. Reporting issuers and securities dealers who wish to sell or distribute securities to potential customers in a particular province must file a prospectus with the regulators of that province and abide by the province's corporate governance laws. While provinces have for the most part modelled their securities regimes on Ontario's Securities Act, R.S.O. 1990 c. S.5., decentralization creates additional hurdles for implementing policies on a national level.

While the patchwork of securities laws may complicate efforts to co-ordinate countrywide strategies, provincial regulators have been working with one another for decades to draft similarly worded legislation and policies to tackle numerous corporate governance issues including gender parity. A poignant example of this cooperative approach towards the regulation of publicly-traded corporations in Canada can be seen in the recent amendments to NI 58-101, which came into force on December 31, 2014 after over five years of consultation between regulators, industry stakeholders, and lawmakers at all levels of government.

\section{Amendments to National Instrument 58-101 and the "Comply or Explain" principle}

NI 58-101 was amended to address the systemic issue of underrepresentation of women on both corporate boards and in the C-suites of TSX-listed companies (Amedment Instrument for NI 58-101, 2014). While NI 58-101 applies to a wide variety of corporate governance issues, the 2014 amendments specifically targeted board renewal, director selection, and executive officer appointment.

Reporting issuers are now required by law to disclose on an annual basis the portions of their corporate governance policies pertaining to the inclusion of women along with their policies related to director term limits (Amedment Instrument for NI 58-101, 2014). For example, reporting issuers must disclose whether or not inclusion policies at the directorship and executive levels have been adopted. Where such policies have Turning Exceptions into the Rule 
been adopted, the reporting issuer is required to disclose its objectives, implementation measures and progress statistics in achieving those objectives. Where corporate governance policies fail to address the representation of women, however, reporting issuers must provide reasons for doing so. Industry observers refer to this regulatory strategy as the "comply or explain" regime (Catalyst Inc., 2016).

\section{Canadian Securities Administrators 2015 Progress Report}

A report prepared by the Canadian Securities Administrators (CSA) released on September 28, 2015 illustrates the impact that the comply or explain amendment has had on corporate governance reform in the realm of equal representation. Regulators from Manitoba, New Brunswick, Newfoundland and Labrador, Northwest Territories, Nova Scotia, Nunavut, Ontario, Québec, Saskatchewan and Yukon jointly reviewed disclosure documents produced by 772 companies listed on the TSX and presented statistics related to the comply or explain amendment in a concise 17page report (CSA Multilateral Staff Notice, 2015).

Of the companies studied, $49 \%$ had at least one woman on their board and $60 \%$ had at least one woman in an executive position (CSA Multilateral Staff Notice, 2015, p. 2). Seeing as there are typically several director seats on any given board, the statistics suggest that Canadian boards remain far below the $30 \%$ target.

Turning Exceptions into the Rule
The inclusion of women varies drastically from industry to industry (see Appendix 2). Women are more likely to be directors or executive officers in the utilities and retail sectors than in other sectors (CSA Multilateral Staff Notice, 2015, p. 12). Of the reporting issuers considered, over $20 \%$ of utilities and retail companies have three or more women on their board (CSA Multilateral Staff Notice, 2015, p. 12). Conversely, Women in the biotech, mining, oil and gas, and technology sectors, are disproportionately underrepresented. Over half of the reporting issuers studied in these sectors have all-male boards (CSA Multilateral Staff Notice, 2015, p. 12).

Very few reporting issuers have created official quotas for appointing women as directors or executives. Roughly seven percent of companies surveyed had established board targets and fewer than two percent had set targets for executive appointments (CSA Multilateral Staff Notice, 2015, p. 12). 39\% of the companies that had established targets did not set timelines for achieving them (CSA Multilateral Staff Notice, 2015, p. 13). Reporting issuers who have not established equal representation quotas have provided a plethora of explanations for not doing so (see Appendix 3). Over 60\% of the noncompliant companies cite a preference for "merit-based selection" as their primary motivation for not adopting targets and roughly $30 \%$ believe targets would be ineffective or based on arbitrary criteria (CSA Multilateral Staff Notice, 2015, p. 10). 
The report also suggests that market capitalization may be strongly correlated with more inclusive corporate governance policies. Companies with a market capitalization of more than $\$ 2$ billion were found to be more than twice as likely to have adopted written policies than companies with market capitalizations between $\$ 1$ billion and $\$ 2$ billion and four times as likely to do so than those with market capitalizations below $\$ 1$ billion (CSA Multilateral Staff Notice, 2015, p. 6). Larger corporations also tended to have more female directors and senior executives than middle-sized and small corporations. Roughly three-fifths of companies with market capitalizations above $\$ 2$ billion had two or more women on their boards. On the other hand, three-fifths of companies with market capitalizations below $\$ 1$ billion had no women on their board whatsoever (CSA Multilateral Staff Notice, 2015, p. 12).

As the CSA report clearly demonstrates, the 'comply or explain' regime has not led to a noticeable increase in the number and proportion of women in senior leadership positions.

\section{Implementing mandatory quotas is the most likely way to achieve greater parity}

Industry observers and stakeholders have proposed a variety of strategies to increase the representation of women in corporate circles including establishing mentorship programmes and offering flexible work arrangements to accommodate women who wish to take maternity leave (Andrew
MacDougall, 2016, p. 34). BMO, for example, has created a mentoring initiative to connect young women with more senior persons in upper management to help guide them through the early stages of their careers (Andrew MacDougall, 2016, p. 34). DHX Media, Manulife and Goldcorp have started similar programs. Teck Resources and Intact Financial Corporation have adopted open policies toward familyfriendly work arrangements to increase female employee retention (MacDougall, 2016, p. 34). These initiatives, while laudable, will not on their own accord lead to gender parity in the boardrooms and Csuites. Mentorship and greater flexibility will certainly help increase female participation in the workforce. Yet, this does not ensure that there will be board seats set aside for women when vacancies arise. Bridging the gender gap and changing corporate culture must start from the boardroom with female directors and executive officers driving the process.

The statistics and numerous reports cited in this paper suggest that the light-handed regulatory approach of using aspirational policies such as the 'comply or explain' regime is not working (Credit Suisse, 2014, p. 5). Reporting issuers have not voluntarily adopted targets as enthusiastically as the provincial regulators would have hoped. Canadian securities regulators must, therefore, resort to imposing mandatory quotas in order to foster more inclusive corporate governance standards across the board. 
Numerous countries in Europe. including Belgium, France, Germany and Italy have passed laws setting quotas. These quotas greatly reduced the gender gaps in their respective national corporate cultures (Kotecha, 2017). Norway, for example, overhauled its voluntary target regime in 2003 and replaced it with a 40\% quota (Catalyst Inc., 2016, p. 27). By doing so, Norway increased its female board representation from 6.8 percent in 2002 to a staggering $35 \%$ by 2014 (Catalyst Inc., 2016, p. 27). The Norwegian experience displays that gender parity is possible and that mandatory quotas do indeed work. Canada should and must follow suit.

Opponents of quotas rely largely on anecdotal evidence to support the argument that mandating gender parity will lead to tokenism. They also continue to argue that quotas would drastically reduce the quality of board appointments notwithstanding the abundance of academic research dispelling these myths (Credit Suisse, 2014). Quotas may in fact have the added benefit of "increased quality boardroom deliberations and overall corporate governance" along with a "more thorough selection process for directors" (Catalyst Inc., 2016, p. 28). Moreover, mandatory quotas can help bring about a paradigmatic shift in popular definitions of "leadership, recognition of unconscious biases and distribution of power," (Catalyst Inc., 2016, p. 28). It is, therefore, in the best interests of not only the regulators and reporting issuers, but also of society at large to encourage Turning Exceptions into the Rule greater boardroom diversity and to strive for more equal gender representation.

\section{Conclusion}

Now is the time for provincial regulators, reporting issuers, and other public stakeholders to take charge and come to terms with reality. Voluntary regimes have not been effective in addressing and eliminating the gender imbalance in corporate Canada. It is time to turn the exceptional leaders on the TSX who have embraced equal representation and more inclusive corporate governance practices into the norm across the Canadian corporate landscape. It is time for mandatory quotas.

\section{References}

Amendment Instrument for NI 58-101 Disclosure of Corporate Governance Practices. (2014). Retrieved July 9, 2017, from Ontario Securities Commission : http://www.osc.gov.on.ca/docume nts/en/SecuritiesCategory5/20141211_58101_amd-governancepractices.pdf

Andrew MacDougall, J. V. (2016). 2016 Diversity Disclosure Practices: Women in leadership roles at TSXlisted companies. Osler, Hoskin \& Harcourt LLP.

Burke, R. J. (2000). Women on Corporate Boards of Directors: Understanding 
the Context. In R. J. Mattis, Women

on Corporate Boards of Directors: International Challenges and Opportunities. Berlin, Germany: Springer Science+Business Media.

Catalyst Inc. (2015). Catalyst Accord: Women On Corporate Boards In Canada. Retrieved July 12, 2017, from Catalyst Inc:: http://www.catalyst.org/catalystaccord-women-corporate-boardscanada

Catalyst Inc. (2016, June 7). Beyond "Comply or Explain": New Catalyst Report for Ontario Government Makes Bold Recommendations to Advance Women on Boards. Retrieved July 10, 2017, from Catalyst Inc.: http://www.catalyst.org/media/bey ond-comply-or-explain-newcatalyst-report-ontariogovernment-makes-boldrecommendations

Catalyst Inc. (2016). Gender Diversity on Boards in Canada: Recommendations for Accelerating Progress. Retrieved July 10, 2017 http://www.catalyst.org/knowledge /gender-diversity-boards-canadarecommendations-acceleratingprogress

Catalyst Inc. (2017, May 10). Statistical Overview of Women In The
Workforce. Retrieved July 9, 2017, from Catalyst Inc: http://www.catalyst.org/knowledge /statistical-overview-womenworkforce

Credit Suisse. (2014). The CS Gender 3000 : Women in Senior Management. Credit Suisse Research Institute . Retrieved from https://publications.creditsuisse.com/tasks/render/file/index. $\mathrm{cfm} ?$ fileid $=8128 \mathrm{~F} 3 \mathrm{CO}-99 \mathrm{BC}-22 \mathrm{E} 6$ 838E2A5B1E4366DF

CSA Multilateral Staff Notice 58-307 Staff Review of Women on Boards and in Executive Officer Positions Compliance with NI 58-101 Disclosure of Corporate Governance Practices. (2015, September 28). Retrieved July 9 , 2017, from Ontario Securities Commission: https://www.osc.gov.on.ca/docume nts/en/Securities-

Category5/csa_20150928_58307_staff-review-womenboards.pdf

Financial Post. (2016, September 26). Women on corporate boards in Canada falls far short of 30 per cent target. Financial Post. Toronto, Ontario, Canada.

(2014). Good for Business: A Plan to Promote the Participation of More Turning Exceptions into the Rule 
Women on Canadian Boards. Government of Canada's Advisory Council for Promoting Women on Boards.

Increasing the Representation of Women

on Canadian Boards. (2016, November 28). Retrieved July 11, 2017, from Government of Canada - Status of Women : http://www.swccfc.gc.ca/initiatives/wldp/wbca/rep-rap-en.html

Kotecha, A. A. (2017, March 22). Canada's approach to board diversity needs a rethink. Globe and Mail. Toronto, Ontario, Canada.

Leighton, D. (2000). Making Boards Work: Recruiting for Balance, Competence and Results. In R. J. Mattis, Women on Corporate Boards of Directors: International Challenges and Opportunities. Berlin, Germany: SpringerScience+Business Media.

Lu, V. (2016, September 28). Virtually no change in getting woman on boards in Canada, stats show. Toronto Star. Toronto, Ontario, Canada.

McFarland, J. (2015, November 24). Board Games: The push for new blood in Canada's boardrooms. Globe and Mail. Toronto, Ontario, Canada.

Sandberg, S. (2013). Lean In: Women, Work, and the Will to Lead. New York: Alfred A. Knopf.

Women Still Missing In Action From Senior Management Positions In Canadian Organizations. (2011, August 31). Retrieved July 10, 2017, from The Conference Board of Canada:

http://www.conferenceboard.ca/pr ess/newsrelease/11-0831/women_still_missing_in_action_f rom_senior_management_position s_in_canadian_organizations.aspx 


\section{Appendix 1}

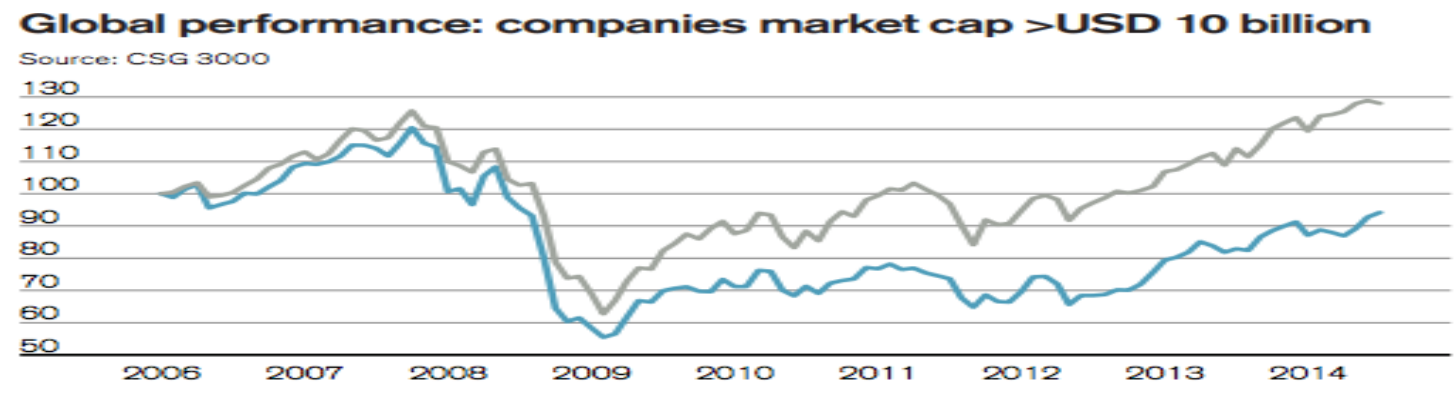

No women on board $\quad 1$ or more women on board

\section{Figure 10}

European performance: companies market cap >USD 10 billion Source: CSG 3000 125

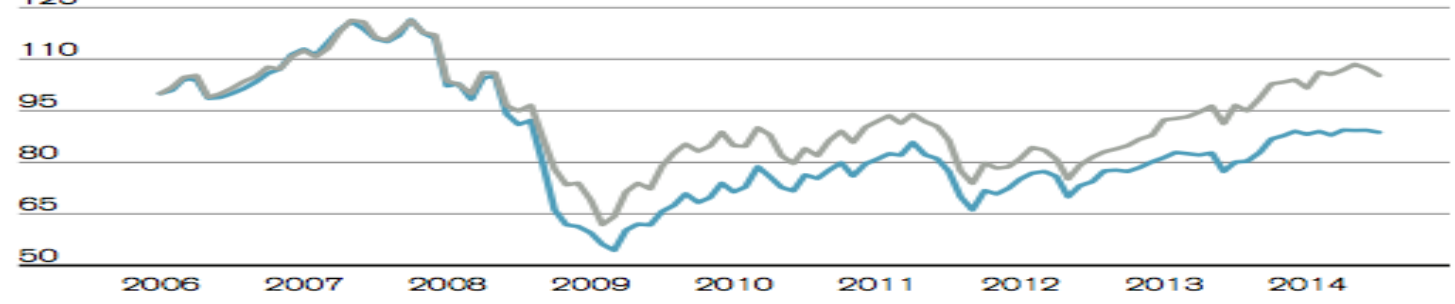

No women on board

1 or more women on board

Figure 11

US performance: companies market cap >USD 10 billion Source: CSG 3000

160

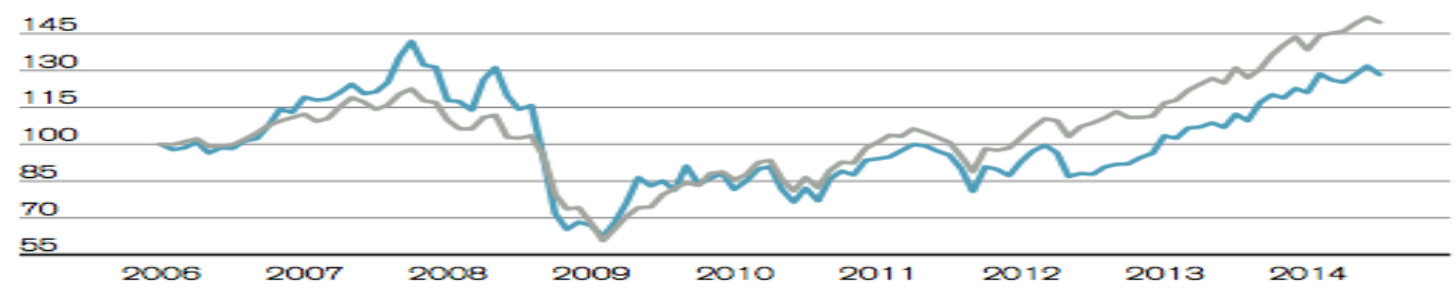

No women on board $\quad 1$ or more women on board

Figure 12

APAC performance: companies market cap > USD 10 billion Source: CSG 3000

160

145

130

115

100

85

70

55
40
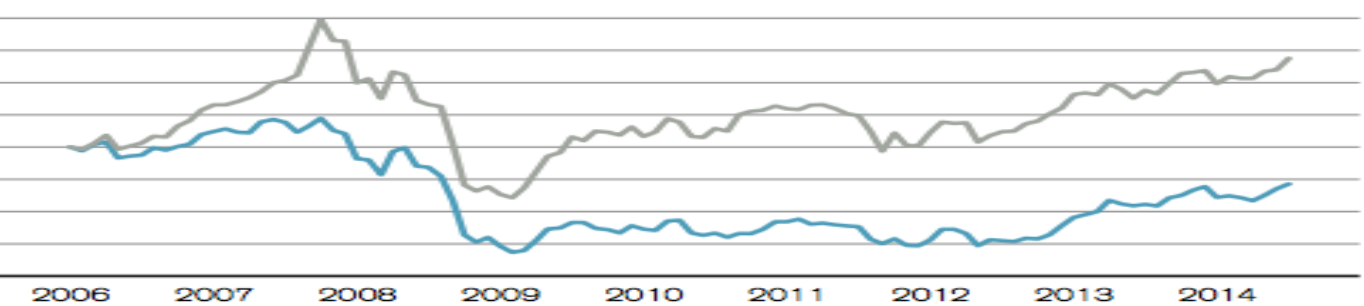

No wornen on board

- 1 or more women on board

Companies with more than one woman on their boards have outperformed their peers.

Note: this figure has been reproduced in its original form.

(Credit Suisse, 2014, p. 23) 


\section{Appendix 2}
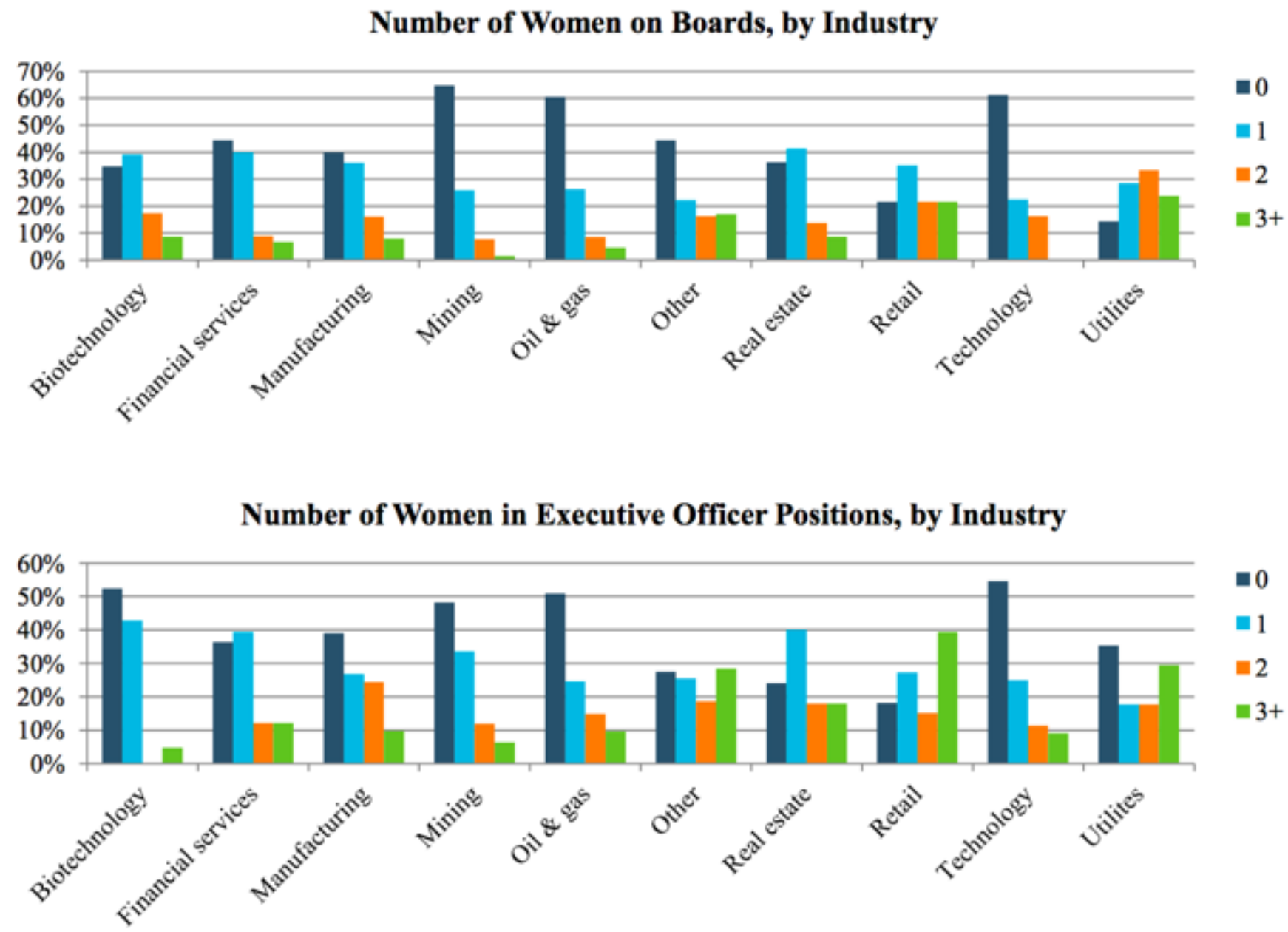

The inclusion of women varies drastically from industry to industry. Female directors and executive officers are more highly represented in the utilities and retail sectors than in other sectors.

Note: this figure has been reproduced in its original form.

(CSA Multilateral Staff Notice, 2015, p. 12) 


\section{Appendix 3}

\section{Reasons Cited for Not Adopting Targets for Women}

Candidates are selected based on merit

Targets would not be effective or are arbitrary

Unduly restrictive or would reduce flexibility

Would not be in issuer's or shareholders' best interest

No reason disclosed

Currently under consideration

Board or executive office group is too small

Want to select candidates from broadest talent pool

Level of gender diversity is already adequate

Industry is male dominated or talent pool is too small

Infrequent director or executive officer turnover

Issuer prefers other formal initiatives for women

Other

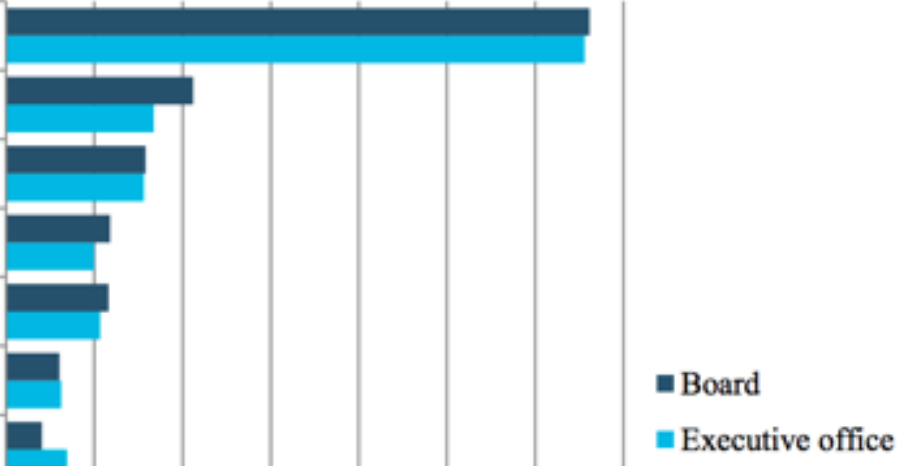

$\begin{array}{llllllll}0 \% & 10 \% & 20 \% & 30 \% & 40 \% & 50 \% & 60 \% & 70 \%\end{array}$

Over $60 \%$ of the non-compliant companies cite a preference for "merit-based selection" as their primary motivation for not adopting targets and roughly $30 \%$ believe targets would be ineffective or based on arbitrary criteria.

Note: this figure has been reproduced in its original form.

(CSA Multilateral Staff Notice, 2015, p. 10) 